\title{
Government Performance and Life Satisfaction in Contemporary Britain
}

\author{
Paul Whiteley University of Essex \\ Harold D. Clarke University of Texas at Dallas, University of Essex \\ David Sanders University of Essex \\ Marianne C. Stewart University of Texas at Dallas
}

\begin{abstract}
This paper investigates relationships between public policy outcomes and life satisfaction in contemporary Britain. Monthly national surveys gathered between April 2004 and December 2008 are used to analyze the impact of policy delivery both at the micro and macro levels, the former relating to citizens' personal experiences, and the latter to cognitive evaluations of and affective reactions to the effectiveness of policies across the country as a whole. The impact of salient political events and changes in economic context involving the onset of a major financial crisis also are considered. Analyses reveal that policy outcomes, especially microlevel ones, significantly influence life satisfaction. The effects of both micro- and macrolevel outcomes involve both affective reactions to policy delivery and cognitive judgments about government performance. Controlling for these and other factors, the broader economic context in which policy judgments are made also influences life satisfaction.
\end{abstract}

$\mathrm{T}$ here has been a significant increase in studies of life satisfaction in recent years. The pioneering work on this topic has been done by psychologists (e.g., Argyle 1987; Diener and Suh 2000; Kahneman, Diener and Schwarz 1999; Mullis 1992; Near and Rechner 1993). In particular, Diener and Veenhoven have made important contributions to clarifying conceptual and measurement issues in the study of subjective well-being (Diener 2009; Veenhoven 1996, 1999). However, a good deal of the recent research has been done by economists with additional contributions by political scientists (e.g., Bruni and Porta 2005, 2007; Bjornskov, Dreher, and Fischer 2007; Easterlin 2002, 2003; Frey 2008; Frey and Stutzer 2000, 2002, 2005; Helliwell 2006; Lane 2000; Layard 2005; Mueller 2008; Nettle 2005; Pacek 2009; Pacek and Radcliff 2008; Radcliff 2001). Some of these studies have begun to investigate the role of the state in affecting subjective well-being. This line of inquiry is important because it is a fundamental premise of democratic theory that political structures and policy outcomes can significantly influence citizens' sense of satisfaction with their lives.
The literature on this topic is small, but it has produced some interesting findings. For example, Frey and Stutzer $(2000,2005)$ demonstrate that life satisfaction in Swiss cantons with high levels of political autonomy and extensive participatory opportunities is greater than in cantons lacking these characteristics. These Swiss findings are an example of what Frey (2008) calls "procedural utility," i.e., satisfaction derived from taking part in politics which is not necessarily related to outcomes. ${ }^{1}$ Additionally, Bjornskov and his colleagues (2007) have conducted a cross-sectional study of 74 countries and report that excessive government consumption appears to decrease life satisfaction. Other recent research by Pacek and Radcliff (Pacek 2009; Pacek and Radcliff 2008; Radcliff 2001) directly considers the impact of government economic and social policies in comparative perspective. They find that government intervention in the economy and generous social policies positively influence life satisfaction.

These latter studies address longstanding controversies about public policy outcomes and subjective well-being. For example, it is well established that

\footnotetext{
${ }^{1}$ This finding echoes earlier studies arguing that expressive motives are important for explaining voting turnout (e.g., Brennan and Buchanan 1984).
}

The Journal of Politics, Vol. 72, No. 3, July 2010, Pp. 733-746

doi:10.1017/S0022381610000137

(C) Southern Political Science Association, 2010

ISSN 0022-3816 
economic growth and unemployment are significantly related to subjective well-being (Kenny 1999; Oswald 1997). These findings raise the question of how public policy outcomes in general are related to wellbeing. In the present paper, we investigate these relationships in one contemporary democratic polityGreat Britain. A unique data set gathered in monthly surveys of the British electorate conducted since April 2004 enables us to examine the dynamics of life satisfaction in this major mature democracy. ${ }^{2}$

To date, most research on subjective well-being has concentrated on relationships at a single point of time, usually in a cross-national comparative setting (e.g., Helliwell 2006; Helliwell and Huang 2008; Oswald 1997; but see Di Tella, MacCulloch, and Oswald 2003; Pacek 2009; Pacek and Radcliff 2008). However, valuable analytic leverage may be obtained by investigating the dynamics of subjective wellbeing, and this is the approach taken in this paper. The analysis covers the period from April 2004 to December 2008 using a series of consecutive monthly cross-sectional surveys. We examine the role of policy delivery at the micro and macro levels, the former relating to citizens' personal experiences, and the latter to their cognitive evaluations of and emotional reactions to the effectiveness of government policies in the country as a whole. In addition, we examine mechanisms that link policy delivery to life satisfaction. A dynamic perspective enables us to investigate how a worsening economic context, in the form of an international financial crisis and a looming recession, can affect life satisfaction net of reactions to policy outcomes and other individual-level influences.

\section{Theoretical Issues}

The growing literature on factors affecting life satisfaction has produced a number of findings. Layard (2005, 63; see also Layard 2006) designates the "Big Seven" predictor variables that typically exert significant effects in multivariate analyses. These variables relate to family relationships and individual financial security, as well as to people's work experiences, their community ties and friendships, health, personal freedom, and individual values. The range of relevant factors is quite broad but, as noted above, political

\footnotetext{
${ }^{2}$ Recognizing the importance of life satisfaction, the British government has appointed Richard Layard "Happiness Tsar" to oversee research on the topic. See http://blog.harvardbusiness. org/corkindale/2009/08/should_work_make_us_happy.html.
}

processes and outcomes have not received a great deal of attention.

It is a fundamental tenet of democratic theory that political structures and processes have sizable effects on citizens' quality of life and their sense of subjective well-being (e.g., Dahl 1972; Lane 2000; Macpherson 1977; Pateman 1970). Recent research by Helliwell (2006) supports this conjecture. Using data gathered in a large number of countries, he examined relationships between life satisfaction and governance indicators developed by World Bank economists (see Kaufmann, Kraay, and Mastruzzi. 2003). The analysis revealed significant differences between developed and developing countries. Governmental honesty and efficiency are quite important in developing countries, whereas voice and accountability, i.e., measures of the quality of the democratic process, are relatively more influential in the developed world (Helliwell 2006; see also Helliwell and Huang 2008). The former factors are linked closely to policy outcomes and the delivery of services, and the latter, to the process of democracy itself. Overall, Helliwell's research suggests that levels of political efficacy help to explain subjective well-being in a mature democracy such as Britain.

Effective public services and successful economic policies also should have a large impact on subjective well-being. This is because, apart from the episodic act of voting, most people never participate in politics, with activities such as protesting and party work being the preserves of small minorities (e.g., Pattie, Seyd, and Whiteley 2004). High rates of nonparticipation will limit the extent to which individuals experience procedural utility. In contrast, all citizens are recipients of public services in one form or another, so it is likely that reactions to public service delivery will have significant effects on how most people feel about their lives.

Another reason why policy delivery should matter is that policy outcomes have important influences on voting behaviour in countries such as Britain (e.g., Clarke et al. 2004, 2009). In particular, what Stokes (1963) called valence issues have large effects on why people support one party rather than another. Valence issues are ones for which there is wide consensus about policy objectives, e.g., delivering economic prosperity, reducing crime, providing affordable, highquality health care. Political disputes involving valence issues focus on "who" and "how" rather than "what," i.e., which parties and leaders are best able to deliver consensually agreed-upon objectives. Since valence issues typically are very salient and people are continually being asked to judge politicians and parties in 
terms of their ability to deliver highly valued goods and services, these issues will focus people's attention in ways that influence their sense of subjective wellbeing.

Notwithstanding findings about the role of procedural utilities in developed countries, policy outcomes may have larger effects than government processes on subjective well-being. Although political efficacy provides a psychological basis for generating procedural utility and affects voting turnout and other forms of citizen involvement, efficacy has remained consistently low in Britain over several decades (Clarke et al. 2004) ${ }^{3}$. If many people remain skeptical about their ability to influence government and opportunities for meaningful citizen involvement are episodic and limited, then the quality of public service delivery-something that is practically always on the "front burner" of political debate and is experienced in various ways by everyone everydaymay be more important than a sense of (in)efficacy.

A final reason for believing policy outcomes are important is that they are related to the "Big Seven" factors that influence life satisfaction mentioned earlier. For example, if health has major effects on subjective well-being, then health care also should be important. If financial security and employment are influential, then so should be the economic policies that affect these factors. Equally, perceptions of personal freedom are likely to be enhanced by crime-free streets and the absence of terrorist threats. Taken together, these several considerations prompt the first hypothesis:

H1: Reactions to policy outcomes at the micro and macro levels have significant effects on life satisfaction.

It bears emphasis that the impact of policy delivery can be evaluated either at the macro or micro levels. The former relate to evaluations of government performance across the country whereas the latter relate to direct personal experiences of receiving services provided by the state. At the macro level, citizens make sociotropic judgments (Kinder and Kiewiet 1981) about policies relating to the economy and public services. Abundant research shows that national economic conditions influence voting behaviour and party support in the period between elections (e.g., Duch and Stevenson 2008; Lewis-Beck 1988; Whiteley 1986). British research also documents that, besides holding governments responsible for the

\footnotetext{
${ }^{3}$ For example, in a 2000 British national survey, 55\% agreed that:

"People like me have no say in what government does" and only $22 \%$ disagreed (Pattie, Seyd, and Whiteley 2004, 45).
}

economy, people hold governments accountable for the state of public service delivery in politically consequential ways (Clarke et al. 2004, 2009). Accordingly, evaluations of national economic conditions and public services should influence feelings of life satisfaction.

It is also noteworthy that political issue agendas have dynamic properties. There has been a significant shift in the British issue agenda over the past decade, with topics associated with personal security such as crime and terrorism gaining salience and competing with traditional issues concerning economic performance and public service delivery (Clarke et al. 2009). Accordingly, it is important to assess how various noneconomic policy outcomes affect subjective well-being.

Public evaluations of macrolevel policies may be partly the product of personal experience, but they also are influenced by other factors including media coverage and the political context in which policy performance judgments are formed (Mutz 1998). In contrast, microlevel judgments are all about personal experience as citizens interact with agents of the state on a daily basis. If an individual calls the police to report a crime, visits their National Health Service doctor, talks to their children's teacher in a state school, or attends a job centre if they become unemployed, they are dealing with agents of the state. Reactions to the effectiveness of these microlevel services are direct and unmediated (Pattie, Seyd and Whiteley 2004). At this level, policy delivery is ever present in peoples' lives, and for this reason it may have a greater influence on life satisfaction than macro evaluations of the economy or public services. Policy outcomes in the micro context are not episodic and remote, but a frequent, even daily, personal experience for most people. Given this, reactions to the delivery of microlevel services may differ from, and be more important, than those related to national policy performance. This suggests a second hypothesis:

H2: Both micro- and macrolevel policy outcomes exert significant influences on life satisfaction. However, microlevel policy outcomes are more important than their macrolevel counterparts.

When individuals form macrolevel judgments about policy delivery, they face problems different from those encountered when they make microevaluations. To evaluate products of complex policy processes of which they have limited experience, citizens require heuristics or rules of thumb to simplify their task. There are debates about the effectiveness of such 
heuristics as devices for processing complex information. Gigerenzer (2008) argues that the use of what he calls "fast and frugal" heuristics can be more effective than full-information processing because the latter is often computationally intractable for actual decisionmaking. Other researchers are content to argue that heuristics can approximate full information processing (e.g., Lupia 1994; Popkin 1991; see also Gigerenzer and Todd 1999). Still others contend that heuristics can badly distort effective decision making (Kuklinski and Quirk 2000, Lavine and Gschwend 2006).

Perhaps the most important device for making judgments relevant to an emotionally charged matter such as life satisfaction is the affect heuristic (Sniderman, Brody, and Tetlock 1991). This heuristic is very easy to apply to the task of evaluating macrolevel policies. For example, if citizens conclude that a governing party is managing the economy effectively because economic outcomes score positively on a subjective "feel good" factor, this solves their decisionmaking problem. Citizens are likely to reward that party with their support, even though they have no clear understanding of how economic policymaking works or why the government has done a good job. All they know-all they need to know-is that they feel good about how the economy is faring.

Affective reactions as cue-giving devices for evaluating the national economy have been examined in the voting literature and the consensus is that they have significant effects on political support (Conover and Feldman 1986; Marcus, Neuman, and MacKuen 2000). Moreover, recent research on affective decision making suggests that the use of this type of heuristic is widespread and acts as an effective preprocessor for cognitive evaluations (Neuman et al. 2007; Nussbaum 2001). Accordingly, a third hypothesis is:

H3: Both cognitive evaluations and affective reactions to policy outcomes influence life satisfaction. However, affective reactions are likely to be more important when citizens consider macropolicy outcomes.

As discussed above, to study the impact of the political process on subjective well-being one needs to consider citizens' evaluations of their ability to play a meaningful role in that process. If people believe that they can influence how political decisions are made, this should increase their subjective wellbeing. Recall that Helliwell (2006) has shown that opportunities for widespread citizen involvement in political life have significant effects on feelings of subjective well-being. We conjecture that such opportunities operate by enhancing citizens' sense of political efficacy. This is consistent with findings in psychology indicating that a sense of personal empowerment significantly affects life satisfaction (e.g., Peterson 1999) and arguments by participatory democratic theorists such as Macpherson (1977) and Pateman (1970). Accordingly, we hypothesize:

H4a: Political efficacy has a significant positive effect on life satisfaction.

And, as per our earlier discussion, we also hypothesize:

H4b: The effect of efficacy on life satisfaction is not as strong as effects associated with policy reactions.

Finally, the broader political and economic contexts in which citizens find themselves also are likely to influence subjective well-being. In this regard, the economic voting literature documents that objective economic variables such as unemployment and inflation rates can have significant effects on political support over and above subjective evaluations of economic conditions (e.g., Lewis-Beck 1988; Sanders et al. 2001). Of course, if there is little variation in macroeconomic variables over time because the economic context is quite stable, then there is unlikely to be much of an impact. However, in the latter part of the period covered by our survey data, the British economy headed into recession following a major crisis in the financial system. This crisis was signalled by the failure of the Northern Rock Bank in the autumn of 2007. The ensuing change in the economic climate after a decade of good times enables us to test a fifth hypothesis:

\section{H5: Changes in the prevailing economic context will influence life satisfaction.}

In addition, major political and economic interventions may be influential. Highly salient events such as general elections and the replacement of a controversial and increasingly unpopular prime minister are examples of political interventions that might affect people's sense of subjective well-being. A fortiori, widely publicized and emotionally evocative "shocks" may exert effects. In the period under consideration such events include the $7 / 7$ terrorist bombing in London in July 2005 and the aforementioned collapse of the Northern Rock bank in autumn 2007. The hypothesis is:

H6: Highly salient political and economic events will influence life satisfaction.

In summary, we advance four theoretical claims. First, accepting that political efficacy can influence subjective well-being, we hypothesize that the effects 
of such "procedural utilities" arising from participatory opportunities are likely to be smaller than those associated with public policy outcomes. Such outcomes relate to the economy and a wide array of public services. Second, we hypothesize that affective evaluations of policy outcomes are likely to be more important than cognitive evaluations as influences on life satisfaction. Third, we conjecture that micropolicy outcomes will be more important than macro ones because the former have direct and unmediated effects on subjective well-being. Finally, we suggest that national events and conditions, particularly the state of the economy, are likely to influence citizens' sense of subjective well-being.

\section{Research Design}

We test the hypotheses articulated above using data generated by the Continuous Monitoring Survey (CMS) component of the British Election Study. ${ }^{4}$ The CMS is an ongoing set of monthly national internet surveys of the British electorate. On average, 1,275 respondents participate in each monthly survey. The CMS data employed here were gathered between April 2004 and December 2008, with nearly 70,000 respondents participating in the surveys. ${ }^{5}$ To model the effects of changes in the macroeconomic context, these individual-level data are supplemented with monthly data on inflation and unemployment rates. To assess the impact of other aspects of the politico-economic context that might influence life satisfaction, we create dummy variables to index salient political and economic events. We employ multilevel modeling techniques (e.g., Raudenbush and Bryk 2002; Snijders and Bosker 1999) to assess the effects of the several aggregate-level variables.

\section{Modelling Life Satisfaction}

Moderate levels of life satisfaction were the norm in Britain over the April 2004-December 2008 period. On average, nearly two-thirds of the CMS respondents stated that they were "very" or "fairly" satisfied with their lives. However, as Figure 1 illustrates, only a relatively small number $(11.7 \%)$ reported that they were "very satisfied." Many more (52.9\%) said they

\footnotetext{
${ }^{4}$ See http://www.essex.ac.uk/bes.

${ }^{5}$ There were two months with no surveys, May 2005 and September 2006.
}

\section{Figure 1 The Distribution of Life Satisfaction in Britain, April 2004-December 2008}

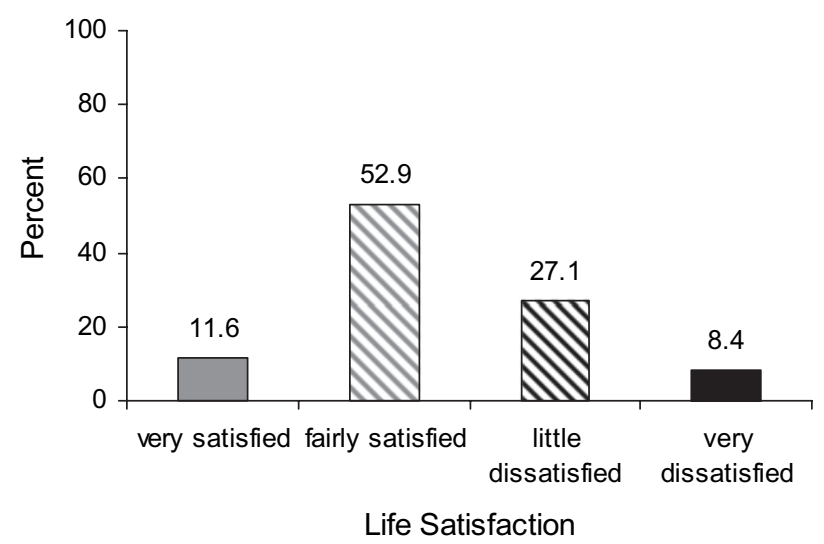

were "fairly satisfied." Respondents who were "a little dissatisfied" constituted slightly over one-quarter $(27.1 \%)$ of the sample, and less than one person in $10(8.4 \%)$ said that they were "very dissatisfied."

Figure 2 shows the percentages of people who said they were at least fairly satisfied with their lives in each of the monthly surveys. This time series is clearly stationary ${ }^{6}$ and exhibits only modest variation over most time intervals, with neither the 2005 general election nor the $7 / 7$ terrorist attack occasioning discernible movements in aggregate life satisfaction. In contrast, the replacement of Tony Blair as prime minister by Gordon Brown prompted a modest and temporary upward pulse. A much larger, abrupt downward movement occurred in October 2007 when life satisfaction fell significantly (by over $10 \%)$ for two months. This decrease coincided with the first visible signs of the emerging economic crisis, which was dramatized by the run on Northern Rock, a major British bank. This was the first such event in Britain in more than 150 years, and it received enormous publicity. In the same two months there was a significant increase in the percentage of respondents who said that they felt "afraid" when they thought about Britain's economic situation. ${ }^{7}$ This suggests that the sudden drop in life satisfaction was driven by the Northern Rock crisis, with the larger implication being that such contextual

\footnotetext{
${ }^{6}$ The visual impression of stationarity in Figure 2 is confirmed by a unit-root test (Enders 2003). The Dickey-Fuller test statistic is -5.48 , which rejects the null hypothesis of nonstationarity at the .01 level.

${ }^{7}$ From September to December 2007 the percentages of people describing themselves as "afraid" when they thought about the economy were $22 \%, 34 \%, 34 \%$, and $27 \%$.
} 
Figure 2 The Dynamics of Life Satisfaction in Britain, April 2004-December 2008

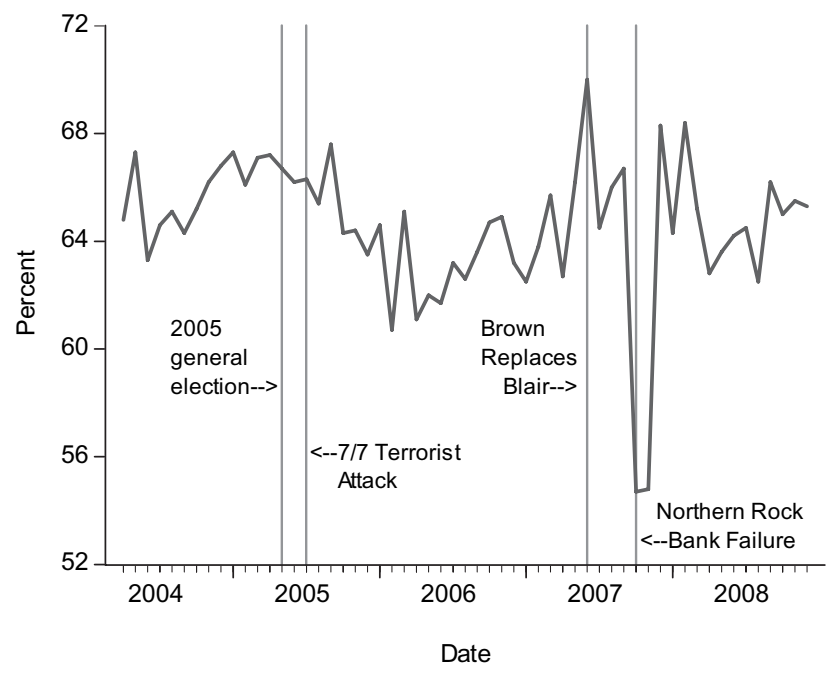

variables can have significant effects on subjective well-being.

We employ individual- and multilevel models to test our hypotheses. Data for individual respondents are at level one, and monthly measures of inflation and unemployment rates are at level two. Additional level two variables include $0-1$ dummies indexing the occurrence of political and economic events discussed above. The individual-level model is a standard ordered logit, and the multilevel model is an ordered logit with a random intercept, which is parameterized to assess the effects of the contextual variables discussed above (see Raudenbush and Bryk 2002).

Details regarding predictor variables are available on the British Election Study website, ${ }^{8}$ but they will be briefly discussed here. Judgments about national and personal economic conditions are separated from other policy performance measures to identify distinct effects. Evaluations of national economic conditions are tapped by two variables measuring retrospective and prospective evaluations. In general, respondents were fairly pessimistic about the economy's performance in the recent past and its future prospects, with only $14 \%$ thinking that the economy had improved over the previous year and also thinking that it would improve in the future. In the multivariate analyses, these items were combined into a single index.

\footnotetext{
${ }^{8}$ See http://www.bes2009-10.org.
}

A second predictor involves evaluations in four noneconomic policy areas-asylum seeking (immigration), crime, health-care, and terrorism. Although these evaluations focus on distinct issues, a principal components analysis revealed that they can be considered indicators of a single latent variable. ${ }^{9}$ This variable provides a global measure of security evaluations, which in the mind of the British public link concerns about crime with judgments about health care, immigration, and the threat of terrorism.

Emotional reactions in various policy areas test the importance of affective heuristics. These reactions were measured by asking respondents to choose descriptors relating to various issues. The list included four positive and four negative words. Positive words were: "hope," "confidence," "pride," and "happiness," and negative words were "anger," "fear," "disgust," and "unease." The affective variables were constructed by computing the number of positive minus the number of negative descriptors selected by each respondent. An index capturing affective reactions to the economy was utilized on its own, whereas affective reactions to security concerns in the areas of crime, health care, immigration, and terrorism were combined into an overall index using a principal components analysis which yielded a one-factor solution. ${ }^{10}$

To measure evaluations of microlevel policy performance, respondents first were asked if they had any personal experience in a particular policy area during the previous 12 months. For example, if a respondent or an immediate member of their family had sought assistance from the police following a crime committed in their home or neighbourhood, this would constitute a personal experience. Such people were then asked if they were satisfied or dissatisfied with how the authorities had dealt with the situation. Answers to these questions provide a direct measure of public evaluations of policy delivery "on the ground." Similar batteries were asked about contact with the National Health Service, experiences with antiterrorism measures such as being searched in airports, and contacts with asylum seekers. A principal components analysis indicated that these several measures could be combined into a single index, with factor scores providing a measure

\footnotetext{
${ }^{9}$ The principal components analysis yields one factor with an eigenvalue greater than 1.0 (1.82), which explains $45.7 \%$ of the item variance.

${ }^{10}$ The factor has an eigenvalue of 2.06 and explains $52.5 \%$ of the item variance.
} 
of satisfaction with policy delivery relating to a variety of security concerns. ${ }^{11}$

Personal experience with the economy was assessed with two questions similar to those tapping national economic evaluations. These retrospective and prospective judgments of a respondent's personal financial situation were combined into an egocentric economic evaluation variable. A second indicator of personal economic experience, (un)employment status, was also included. Finally, procedural utility arising from a sense of political efficacy was measured using an 11-point scale of the extent of perceived influence on politics and public affairs.

The life satisfaction model also includes controls for several other factors. Marital relationships were assessed by $0-1$ dummy variables indicating if a respondent was single, divorced, living with a partner but unmarried, or widowed (being married was the reference category). Financial security was measured using annual family income and home ownership, and work experience, by occupational status and retirement status. Community ties were captured by voluntary work in one's neighbourhood, and also by sense of interpersonal trust, a key indicator of social capital (e.g., Putnam 2000). Personal health was indexed by a dummy variable indicating if a respondent was disabled. Gender, ethnicity, and age were included as additional controls.

The contextual (aggregate) level of the model included six variables. Two measures of the objective state of the economy-inflation and unemployment rates-assess variations in the economic context. Given that previous research has found that individual unemployment strongly affects life satisfaction, it is important to investigate the impact of aggregate unemployment as a measure of the economic context. In addition, a 0-1 dummy variable was constructed to capture the impact of the arrival of the economic crisis in Britain. This was the collapse of Northern Rock which occurred in October and November 2007. A second dummy variable indexing the general election of May 2005 was included to explore the effects of a national election-a major symbol of the democratic bona fides of the British political system. A third dummy variable was used to study the impact of the replacement of an incumbent prime minister. This event occurred in June 2007 when the unpopular Tony Blair exited 10 Downing Street in favor of Gordon Brown who, at the time, was greeted with wide public enthusiasm. A fourth

\footnotetext{
${ }^{11}$ The factor has an eigenvalue of 1.29 and explains $32.2 \%$ of the item variance.
}

dummy variable marked the occurrence of the $7 / 7$ terrorist bombings in London in July 2005.

\section{Empirical Results}

A first step in the analysis involved estimating a single-level ordered logistic model of life satisfaction with individual-level data pooled across the entire period. ${ }^{12}$ This model can be used to test the first four hypotheses discussed earlier. The results are shown in Table 1. To facilitate interpretation, the impact of each predictor on the probability of individuals being at least fairly satisfied with their lives is depicted in Figure 3. This figure shows the change in probability of being satisfied with life as each continuous predictor variable is varied across a range of two standard deviations below its mean to two standard deviations above with other predictors set at their means. Dichotomous predictors are varied from 0 to 1 , with continuous predictors set at their means. ${ }^{13}$

The first hypothesis states that micro- and macrolevel policy outcomes have significant influences on subjective well-being. Estimated coefficients are consistent with this hypothesis (see Table 1). With the sole exception of the measure of cognitive evaluations of national economic conditions, all of the policy indicators, both at the micro and macro levels, have statistically significant $(\mathrm{p}<.001)$ and properly signed effects.

The second hypothesis, which states that microlevel outcomes have stronger effects than macrolevel ones, is also supported. As Figure 3 shows, increasingly positive personal economic evaluations enhance the probability of being satisfied with one's life by .49 whereas, as just noted, the impact of national economic evaluations is statistically insignificant. The story for noneconomic policy evaluations is quite

\footnotetext{
${ }^{12}$ Given the large number of predictors used either alone or in various indices and the plausible assumption that data are not missing completely at random, listwise deletion is not a viable option if sample integrity is to be maintained. Here, we use mean substitution for continuous variables and midpoint substitution for ordinal-scale variables (e.g., recoding “don't know” responses to the "neither agree nor disagree" category of 5-point Likert scales). Given the extremely large sample size $(\mathrm{N}=69,750)$, concern that these procedures will underestimate standard errors is not an issue.

${ }^{13}$ All of the marital status dummy variables are initially set to 0 , and then each of them is set to 1 in turn. This permits computation of the probability of being satisfied with life associated with membership in one of the designated categories (living as married, divorced, single, widowed) compared to being married (the reference category).
} 


\section{FIgURE 3 Change in Probability of Being "Fairly" or "Very" Satisfied with Life Associated with Various Predictor Variables}

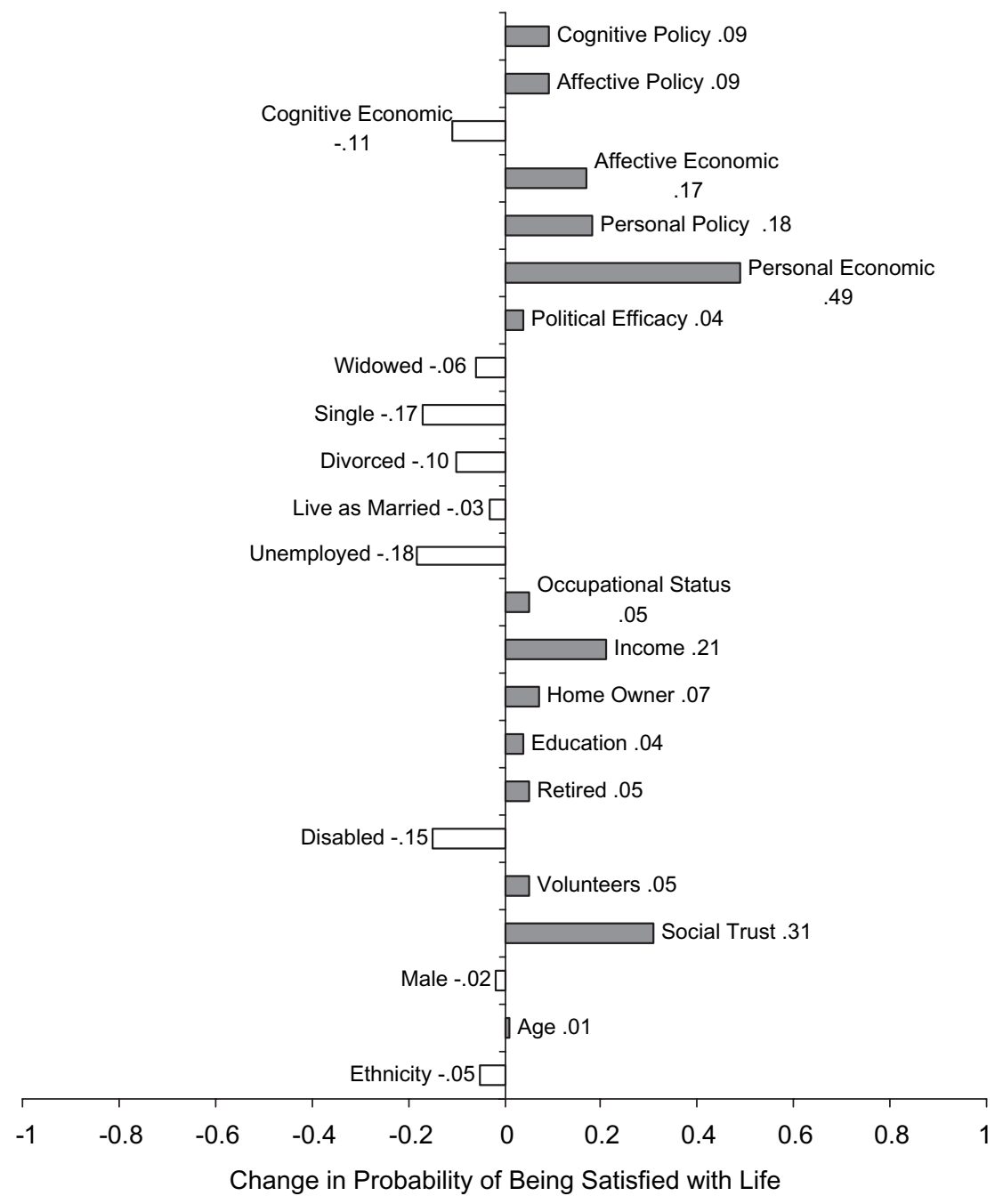

Note: change in probability of being satisfied with life produced by $+/$ - two standard deviation change in continuous predictor variables, and $0-1$ shift in dichotomous predictor variables.

similar. As microlevel (personal) policy evaluations move from negative to positive, the probability of being satisfied with life increases by .18. The comparable increase for macrolevel (national) policy evaluations is half as large, .09. These numbers indicate that satisfactory personal treatment by an agent of the state is more important to citizens than believing that the government has done a good job in managing policies at the national level.

The third hypothesis states that, at the macrolevel, individuals rely heavily on an affect heuristic when making judgments about policy performance. This hypothesis is supported up to a point, but it is more apparent in the case of the economy than for evaluations of personal security. As Table 1 shows, the effects of affective economic evaluations are both positive and statistically significant, whereas as noted above cognitive economic evaluations do not have a significant impact on life satisfaction. With other predictors held at their means, increases in affective reactions to the economy change the probability of being satisfied with one's life by .17 (see Figure 3 ). These results suggest that, in relation to the national economy, feelings of life satisfaction are influenced primarily by an affect heuristic. Regarding personal security, this heuristic is again apparent since emotional reactions have a significant, positive impact on life satisfaction, but cognitive evaluations have a larger effect (.09 v. .18). Viewed generally, these results indicate that cognitions are not all; 'gut' 
TABle 1 Individual-Level Ordered Logit Model of Life Satisfaction, April 2004-December 2008

\begin{tabular}{|c|c|c|}
\hline Predictor Variables & $\beta$ & s.e. \\
\hline Cognitive Policy Evaluations & $0.092^{\star * *}$ & 0.009 \\
\hline Affective Policy Evaluations & $0.103^{\star * *}$ & 0.009 \\
\hline Cognitive Evaluations of Economy & -0.065 & 0.006 \\
\hline Affective Reactions to Economy & $0.104^{\star \star \star}$ & 0.006 \\
\hline Personal Economic Evaluations & $0.336^{\star * \star}$ & 0.006 \\
\hline Personal Policy Experiences & $0.199^{\star * \star}$ & 0.008 \\
\hline Political Efficacy & $0.020^{\star * *}$ & 0.004 \\
\hline Interpersonal Trust & $0.169^{\star * \star}$ & 0.004 \\
\hline Volunteers in Local Community & $0.186^{\star * *}$ & 0.019 \\
\hline Age & $-0.048^{\star * *}$ & 0.004 \\
\hline Age Squared & $0.001^{\star * *}$ & 0.00004 \\
\hline Disability & $-0.612^{\star * *}$ & 0.033 \\
\hline Education & $0.029^{* * *}$ & 0.006 \\
\hline Ethnic Minority & $-0.207^{\star * *}$ & 0.031 \\
\hline Gender & $-0.098^{\star * \star}$ & 0.016 \\
\hline Home Ownership & $0.314^{* * *}$ & 0.019 \\
\hline Income & $0.112^{* * *}$ & 0.005 \\
\hline Occupational Status & $0.031^{* * *}$ & 0.005 \\
\hline Retired & $0.231^{* * *}$ & 0.029 \\
\hline Unemployed & $-0.762^{\star * \star}$ & 0.046 \\
\hline Marital Status: Living as Married & $-0.192^{\star * *}$ & 0.025 \\
\hline Divorced & $-0.470^{\star * \star}$ & 0.028 \\
\hline Single & $-0.515^{\star * *}$ & 0.024 \\
\hline Widowed & $-0.298^{\star * *}$ & 0.045 \\
\hline
\end{tabular}

McKelvey $\mathrm{R}^{2}=.30$

Percentage Correctly Classified (4 categories) $=56.9$

Percentage Correctly Classified $(2$ categories $)=72.9$

Log-likelihood $=-67862.001$

$\mathrm{N}=67,950$

$* * *-\mathrm{p}<.001$, one-tailed test.

feelings about policy outcomes are a significant source of life satisfaction.

Part A of the fourth hypothesis states that political efficacy is positively related to life satisfaction. This hypothesis receives empirical support, with the efficacy coefficient having the expected positive and statistically significant $(\mathrm{p}<.001)$ effect. However, as conjectured in part B of hypothesis four, the effect of political efficacy is not as great as those associated with cognitive and affective reactions to macro- and microlevel policy outcomes. With other predictors held at their means, variations in efficacy produce only a .04 change in the probability of being satisfied with one's life (see Figure 3). As observed, comparable figures for policy reactions vary from .09 (noneconomic policy evaluations) to .49 (personal economic evaluations).

All control variables also behave as expected. Being single, divorced, widowed, or living with an unmarried partner all reduce life satisfaction relative to being married (see Table 1 and Figure 3). Financial security is important since income and home ownership are both significant positive predictors. The effect of income is quite strong and can change the probability of being satisfied with life by .21 . Work experience, as measured by occupational and retirement statuses, also increases life satisfaction, although, as shown in Figure 3, the effects are modest (.05 in each case). Community ties matter more since interpersonal trust has a very strong influence. Ceteris paribus, increasing social trust can enhance the probability of being fairly or very satisfied with one's life by .31. Voluntary activity in one's neighbourhood also has a positive impact, albeit a considerably more modest one (.05 points). These findings are consistent with arguments advanced by Putnam (2000) and others that social capital enhances life satisfaction. In addition, persons with disabilities, men, and ethnic minorities tend to have lower levels of life satisfaction, although the latter two effects are quite modest. Finally, the effect of age is such that an initial negative impact of aging is eventually reversed. The resulting 
effect across the life span is very small, with the very elderly having a .01 greater probability of being satisfied with life.

The fifth and sixth hypotheses are tested by incorporating aggregate-level variables in the model using a multilevel specification. The first step in this analysis is to determine if there are significant shifts in life satisfaction over time when the several predictors in the individual-level model have been taken into account. A chi-square test of the variance of the random intercept term is highly significant $\left(\chi^{2}=\right.$ $467.16, \mathrm{df}=54, \mathrm{p}<.001)$, indicating that subjective well-being does indeed change over time even with all of the individual-level variables in place. ${ }^{14}$ This finding is consistent with the general proposition that contextual covariates play a role in determining life satisfaction.

One expectation is that rising unemployment will reduce life satisfaction. Joblessness accelerated towards the end of 2008 as the global financial crisis began to influence Britain's real economy. Given this dynamic, one might expect unemployment to have a negative, but nonlinear, effect on life satisfaction. This nonlinearity may be seen as an aggregate-level analogue to a process of hedonic adaptation which can occur as individuals adjust their level of life satisfaction to changes in personal circumstances such as increases in personal income (Brickman and Campbell 1971). ${ }^{15}$ Here, the idea is that individuals may adapt to a new economic context and so begin to get used to new, higher levels of unemployment. To investigate this possibility, the effect of unemployment is examined by means of a quadratic specification.

The expected effects of inflation are less clear cut. Although people dislike price increases, British consumers have grown used to rather low levels of inflation in recent years. Thus, modest price increases may very well signal a buoyant economy rather than a threat to purchasing power. If there is an unrealized inflationary threshold which has to be crossed before

\footnotetext{
${ }^{14}$ Multilevel model coefficients are estimated using HLM 6.4 (Rudenbush et al. 2004).

${ }^{15}$ Frey discusses this process in relation to the utility derived from increased income in the following terms: "Additional material goods and services initially provide extra pleasure, but it is usually transitory. Higher utility from material goods wears off. Satisfaction depends on change and disappears with current consumption" $(2008,32)$. In the language of time-series analysis, the hypothesis is that life satisfaction follows a pulse-decay pattern in reaction to increases in personal income. This process is often called the "hedonic treadmill." Recent studies using longitudinal data from the British Household Panel Study and other sources indicate that such treadmill effects are not inevitable (see, e.g., Hansson 2009).
}

it is perceived to be a serious problem, then price changes may not be important as contextual measures. Other aggregate-level covariates include dummy variables for the Northern Rock crisis, the 2005 general election, the $7 / 7$ terrorist attack and the change in prime minister in July 2007. These several aggregate effects are investigated using a random intercepts specification. Coefficients associated with the several contextual variables indicate how they influence variations in the intercept of the individuallevel model.

The results are shown in Table 2. Controlling for all other predictors, the Northern Rock crisis had the predicted negative effect on life satisfaction. In addition, rising unemployment reduced subjective wellbeing in a highly significant way but with a declining impact as the quadratic specification indicates. Overall, the individual-level and contextual effects of unemployment reinforce each other, with individuals adapting to rising aggregate-level unemployment. In contrast, inflation does not have a significant impact which, as suggested above, may reflect the slow pace of price increases over the past decade. Similarly, none of the political interventions - the 2005 general election, the $7 / 7$ terrorist bombings, the installation of Gordon Brown as prime minister-were influential. Overall, the effects of individual-level variables in the multilevel model differ only slightly from the estimates for the single-level model in Table 1. Again, the big story is that a mix of affective reactions and cognitive evaluations drive life satisfaction and that personal experience with policy delivery in economic and other policy realms matters.

\section{Conclusion: Government Performance and Life Satisfaction}

Several factors related to government performance and the political process affect citizens' sense of subjective well-being. If people believe that they can influence the political process, this increases their life satisfaction. However, microlevel, i.e., personal, policy outcomes relating to the economy, crime and other security related issues are considerably more important than efficacy and also are more important than macrolevel, i.e., national, policy evaluations. A government seeking to enhance the subjective wellbeing of its citizens needs to ensure that public service delivery on the ground works well.

Viewed generally, present findings highlight the importance of microlevel policy delivery, a topic that 
Table 2 Multilevel Ordered Logit Model of Life Satisfaction, April 2004-October 2008

\begin{tabular}{|c|c|c|}
\hline Aggregate-Level Model & $\gamma$ & s.e. \\
\hline Constant & 1.406 & 1.797 \\
\hline Run on Northern Rock Bank & $-0.543^{\star * *}$ & 0.105 \\
\hline Inflation & 0.081 & 0.044 \\
\hline Unemployment & $-4.391^{\star * *}$ & 1.236 \\
\hline Unemployment Squared & $0.751^{\star * *}$ & 0.212 \\
\hline 2005 General Election & -0.072 & 0.117 \\
\hline 7/7 Terrorist Attack & -0.008 & 0.116 \\
\hline Replacement of Blair by Brown & 0.077 & 0.121 \\
\hline Individual-Level Model & $\pi$ & s.e. \\
\hline Cognitive Policy Evaluations & $0.078^{\star * *}$ & 0.009 \\
\hline Affective Policy Evaluations & $0.091^{\star * \star}$ & 0.009 \\
\hline Cognitive Evaluations of Economy & $-0.041^{\star * *}$ & 0.007 \\
\hline Affective Reactions to Economy & $0.107^{\star * *}$ & 0.006 \\
\hline Personal Economic Evaluations & $0.340^{\star * \star}$ & 0.006 \\
\hline Personal Policy Experiences & $0.193^{\star \star \star}$ & 0.008 \\
\hline Political Efficacy & $0.019^{* * *}$ & 0.004 \\
\hline Interpersonal Trust & $0.168^{\star * *}$ & 0.004 \\
\hline Volunteers in Local Community & $0.199^{\star * *}$ & 0.019 \\
\hline Age & $-0.049^{\star \star \star *}$ & 0.004 \\
\hline Age Squared & $0.001^{\star * *}$ & 0.00004 \\
\hline Disability & $-0.609^{* * *}$ & 0.032 \\
\hline Education & $0.029^{\star * *}$ & 0.006 \\
\hline Ethnic Minority & $-0.211^{\star * *}$ & 0.031 \\
\hline Gender & $-0.097^{\star * *}$ & 0.016 \\
\hline Home Ownership & $0.319^{\star * *}$ & 0.019 \\
\hline Income & $0.110^{\star * \star}$ & 0.005 \\
\hline Occupational Status & $0.033^{\star * *}$ & 0.005 \\
\hline Retired & $0.228^{* * *}$ & 0.029 \\
\hline Unemployed & $-0.760^{\star * \star}$ & 0.046 \\
\hline Marital Status: Living as Married & $-0.203^{\star * *}$ & 0.025 \\
\hline Divorced & $-0.477^{\star * \star}$ & 0.028 \\
\hline Single & $-0.528^{\star * *}$ & 0.024 \\
\hline Widowed & $-0.308^{\star * \star}$ & 0.045 \\
\hline
\end{tabular}

$\mathrm{N}=67,955$

$* * *-\mathrm{p}<.001$, one-tailed test.

Paul F Whiteley is Professor of Government at the University of Essex, Colchester, Essex, CO4 3SQ, United Kingdom

has been largely neglected in studies of subjective well-being. Moreover, such are the complexities of policy delivery at the national level that citizens rely on a mixture of cognitive evaluations and affective heuristics. Context also matters, as indicated by the negative effects of unemployment rates and the Northern Rock crisis in our multilevel model. These latter results convey a methodological message as well, highlighting the importance of using large amounts of survey data gathered over closely spaced time intervals. This type of research design is essential to turn a single-country context from a constant into a series of theoretically interesting variables.
The broad conclusion is that how democratic governments operate and what they do have a variety of effects on life satisfaction. Previous research has found that the structure and extent of opportunities for meaningful political participation are influential. Without gainsaying these effects, we find that personal experiences resulting from local-level interactions with state agents and programs have larger impacts. Effects of evaluations of personal economic circumstances are larger still.

Although impressive, personal experiences are not the whole story. Rather, to the extent that governments can produce a range of felicitous policy outcomes, 
positive sociotropic effects are important. On the downside, economic shocks such as the failure of a major bank also matter. When such an event occurs, the result will be at least a short-run decrease in the public's sense of subjective well-being. Depending upon their severity and duration, more general economic downturns may have longer lived negative effects.

In sum, if governments can control the delivery of economic and other policy outcomes, they can affect the subjective well-being of citizens in predictable ways. This idea long has been a basic tenet in the democratic theory literature and, historically, it has been a key aspect of political discourse surrounding the development of the modern welfare state. Our empirical analyses indicate that it is correct. In a contemporary mature democracy such as Great Britain, government policy performance is an important element in the story of life satisfaction.

An important implication is that empirical research on subjective well-being can address important public policy debates. For example, affirmative action and diversity programs designed to benefit historically disadvantaged minorities long have been contentious features of public policy debate in the United States and other advanced democracies. Can such programs be "Pareto improvements," i.e., can their implementation increase the subjective wellbeing of their actual or potential beneficiaries, while leaving feelings of well-being in the wider society unchanged, or perhaps even enhanced? Similarly, are there empirically grounded utilitarian justifications for various levels and patterns of state benefits and redistribution? Do particular welfare programs enhance or diminish the sum total of subjective wellbeing in a society? Such issues have been debated for decades, and results of studies of life satisfaction in mass publics can make meaningful contributions to their resolution. These examples illustrate the attractiveness of a broad, policy-relevant research agenda involving relationships between government and subjective well-being. Pursuing that agenda constitutes an interesting and important avenue for future research.

\section{Acknowledgments}

We wish to thank the UK Economic and Social Research Council and the US National Science Foundation for financial support that enabled us to gather the survey data presented in this article. We particularly appreciate the interest in our work shown by Gary Williams at the ESRC and Brian Humes, Jim Granato and Frank Scioli at the NSF.
Manuscript submitted 4 August 2009

Manuscript accepted for publication 26 October 2009

\section{References}

Argyle, Michael. 1987. The Psychology of Happiness. London: Methuen.

Bjornskov, Christian, Axel Dreher, and A. V. Justina Fisher. 2007. "The Bigger the Better? Evidence of the Effect of Government Size on Life Satisfaction around the World." Public Choice 130 (1/2): 267-92.

Brennan, Geoffrey, and James Buchanan. 1984. "Voter Choice: Evaluating Political Alternatives." American Behavioral Scientist 28 (2): 185-201.

Brickman, P., and David T. Campbell. 1971. "Hedonic Relativism and Planning the Good Society." In Adaptation-Level Theory: A Symposium, ed. Mortimer H. Appley. New York: Academic Press.

Bruni, Luigino, and Pier Luigi Porta. 2005. Economics and Happiness: Framing the Analysis. Oxford: Oxford University Press.

Bruni, Luigino, and Pier Luigi Porta, eds. 2007. Handbook on the Economics of Happiness. London: Edward Elgar.

Clarke, Harold. D., Marianne Stewart, David Sanders, and Paul Whiteley. 2004. Political Choice in Britain. Oxford: Oxford University Press.

Clarke, Harold. D., Marianne Stewart, David Sanders, and Paul Whiteley. 2009. Performance Politics and the British Voter. Cambridge: Cambridge University Press.

Conover, Pamela, and Stanley Feldman. 1986. "Emotional Reactions to the Economy: I'm Mad as Hell and I'm Not Going to Take It Any More." American Journal of Political Science 30 (1): 50-78.

Dahl, Robert A. 1972. Polyarchy: Participation and Opposition. New Haven, CT: Yale University Press.

Diener, Ed, and Eunkook Suh, eds. 2000. Culture and Subjective Well-Being. Cambridge, MA: MIT Press.

Diener, Ed, ed. 2009. Culture and Well-Being: The Collected Works of Ed Diener. Heidelberg: Springer Dordrecht.

Di Tella, Rafael, Robert MacCulloch, and Andrew Oswald. 2003. "The Macroeconomics of Happiness." Review of Economics and Statistics 85 (4): 809-27.

Duch, Ray, and Randolph T. Stevenson. 2008. The Economic Vote: How Political and Economic Institutions Condition Election Results. Cambridge: Cambridge University Press.

Easterlin, Richard, ed. 2002. Happiness in Economics. London: Edward Elgar.

Easterlin, Richard. 2003. "Explaining Happiness." Proceedings of the National Academy of Sciences 100 (19): 11176-11183.

Enders, Walter. 2003. Applied Econometric Time Series. 2nd edition. New York: John Wiley \& Sons.

Frey, Bruno S. 2008. Happiness: A Revolution in Economics. Cambridge, MA: MIT Press.

Frey, Bruno S., and Alois Stutzer. 2000. "Happiness, Economy and Institutions." Economic Journal 110 (446): 918-38.

Frey, Bruno S., and Alois Stutzer. 2002. Happiness and Economics. Princeton, NJ: Princeton University Press.

Frey, Bruno S., and Alois Stutzer. 2005. "Happiness Research: State and Prospects." Review of Social Economy 63 (2): 207-28. 
Gigerenzer, Gerd. 2008. Rationality for Mortals. Oxford: Oxford University Press.

Gigerenzer, Gerd, and Peter M. Todd. 1999. Simple Heuristics That Make Us Smart. Oxford: Oxford University Press.

Hansson, Anna. 2009. Subjective Well-Being and Adult Swedish Population. Stockholm: Karolinska Institutet.

Helliwell, John. 2006. "Well-Being, Social Capital and Public Policy: What's New?" Economic Journal 116 (510): C34-C45.

Helliwell, John, and Huang Haifang. 2008. "How's Your Government? International Evidence Linking Good Government and Well-Being." British Journal of Political Science 38 (4): 595619.

Kahneman, Daniel, Ed Diener, and Norbert Schwarz, eds. 1999. Well-Being: The Foundations of Hedonic Psychology. New York: Russell Sage Foundation.

Kaufmann, Daniel, Aart Kraay, and Massimo Mastruzzi. 2006. "Governance Matters V: Aggregate and Individual Governance Indicators for 1996-2005." Washington, DC: World Bank.

Kenny, Charles, 1999. "Does Growth Cause Happiness or Does Happiness Cause Growth?” Kyklos 52 (1): 3-26.

Kinder, Donald R., and Roderick D. Kiewiet. 1981. "Sociotropic Politics: The American Case." British Journal of Political Science 11 (2): 129-62.

Kuklinski, James H., and Paul J. Quirk. 2000. "Reconsidering the Rational Public." In Elements of Reason, eds. Arthur Lupia, Mathew McCubbins, and Samuel L. Popkin. Cambridge: Cambridge University Press, 153-80.

Lane, Robert E. 2000. The Loss of Happiness in Market Economies. New Haven, CT: Yale University Press.

Lavine, Howard, and Thomas Gschwend. 2006. "Issues, Party and Character: The Moderating Role of Ideological Thinking on Candidate Evaluation." British Journal of Political Science 37 (1): 139-63.

Layard, Richard. 2005. Happiness: Lessons from a New Science. London: Penguin.

Layard, Richard. 2006. "Happiness and Public Policy: A Challenge to the Profession." Economic Journal 116 (510): c24-c33.

Lewis-Beck, Michael. S. 1988. Economics and Elections: The Major Western Democracies. Ann Arbor: University of Michigan Press.

Lupia, Arthur. 1994. "Shortcuts versus Encyclopedias: Information and Voting Behavior in California Insurance Reform Elections." American Political Science Review 88 (1): 63 76.

Marcus, George E., W. Russell Neuman, and Michael MacKuen. 2000. Affective Intelligence and Political Judgment. Chicago: University of Chicago Press, 2000.

Macpherson, C. B. 1977. The Life and Times of Liberal Democracy. Oxford: Oxford University Press.

Mueller, Georg P. 2008. "Trust and Life Satisfaction in Eastern and Western Europe." In Quality of Life and the Millennium Challenge, eds. Valerie Moller and Denis Huschka. New York: Springer Science, 161-76.

Mullis, Randolph J. 1992. "Measures of Economic Well- Being as Predictors of Psychological Well-Being." Social Indicators Research 26 (2): 119-35.

Mutz, Diana C. 1998. Impersonal Influence: How Perceptions of Mass Collectives Affect Political Attitudes. Cambridge: Cambridge University Press.
Near, Janet P., and Paula L. Rechner. 1993. "Cross-Cultural Variations in Predictors of Life Satisfaction: An Historical View of Differences among Western European Countries." Social Indicators Research 29 (1): 109-21.

Nettle, Daniel. 2005. Happiness: The Science Behind Your Smile. Oxford: Oxford University Press.

Neuman, W. Russell, George E. Marcus, Ann N. Crigler, and Michael MacKuen, eds. 2007. The Affect Effect: Dynamics of Emotion in Political Thinking and Behavior. Chicago: University of Chicago Press.

Nussbaum, Martha. 2001. Upheavals of Thought: The Intelligence of Emotions. Cambridge: Cambridge University Press.

Oswald, Andrew. 1997. "Happiness and Economic Performance." Economic Journal 107 (445): 1815-31.

Pacek, Alexander. 2009. "Politics Vs. Markets in the Diffusion of Human Well-Being: A Cross-National Analysis." Unpublished paper. Texas A \& M University.

Pacek, Alexander, and Benjamin Radcliff. 2008. "Assessing the Welfare State: The Politics of Happiness." Perspectives on Politics 6: 267-77.

Pateman, Carole. 1970. Participation and Democratic Theory. Cambridge: Cambridge University Press.

Pattie, Charles, Patrick Seyd, and Paul Whiteley. 2004. Citizenship in Britain: Values, Participation and Democracy. Cambridge: Cambridge University Press.

Peterson, Christopher. 1999. "Personal Control and Well-Being." In Well-Being: The Foundations of Hedonic Psychology, eds. Daniel Kahneman, Ed Diener, and Norbert Schwarz. New York. Russell Sage Foundation, 288-301.

Popkin, Samuel L. 1991. The Reasoning Voter: Communication and Persuasion in Presidential Campaigns. Chicago: University of Chicago Press.

Putnam, Robert. 2000. Bowling Alone: The Collapse and Revival of American Community. New York: Simon \& Schuster.

Radcliff, Benjamin. 2001. "Politics, Markets and Life Satisfaction." American Political Science Review 95 (4): 939-52.

Raudenbush, Stephen W., and Anthony S. Bryk. 2002. Hierarchical Linear Models: Applications and Data Analysis Methods. $2^{\text {nd }}$ ed. Thousand Oaks, CA: Sage Publications.

Raudenbush, Stephen W., Anthony S. Bryk, Uk Fai Cheong, and Richard T. Congdon, Jr. 2004. HLM 6: Hierarchical Linear and Nonlinear Modeling. Chicago: Scientific Software.

Sanders, David, Harold Clarke, Marianne Stewart, and Paul Whiteley 2001. "The Economy and Voting." In Britain Votes 2001, ed. Pippa Norris. Oxford: Oxford University Press, 22538.

Sniderman, Paul M., Richard A. Brody, and Phillip E. Tetlock, eds. 1991. Reasoning and Choice: Explorations in Political Psychology. Cambridge: Cambridge University Press.

Snijders, Tom, and Roel Bosker. 1999. Multilevel Analysis: An Introduction to Basic and Advanced Multilevel Modeling. London: Sage.

Stokes, Donald E. 1963. "Spatial Models of Party Competition." American Political Science Review 57 (2): 368-77.

Veenhoven, Ruut. 1996. "Developments in Satisfaction Research." Social Indicators Research 37 (1): 1-46.

Veenhoven, Ruut. 1999. "Quality of Life in Individualistic Society: A Comparison of 43 Nations in the Early 1990s." Social Indicators Research 48 (2): 157-86.

Whiteley, Paul. 1986. Political Control of the Macroeconomy. London: Sage 
Paul F. Whiteley is Professor of Government at the University of Essex, Colchester, Essex, CO4 3SQ, United Kingdom

Harold D. Clarke, Ashbel Smith Professor of Economic, Political and Policy Sciences, University of Texas at Dallas, Richardson TX, 75083.
David Sanders is Professor of Government at the University of Essex, Colchester, Essex, CO4 3SQ, United Kingdom

Marianne Stewart, Professor of Economic, Political and Policy Sciences, University of Texas at Dallas, Richardson TX, 75083. 